\title{
KEDUDUKAN PERJANJIAN PENGIKATAN JUAL BELI HAK ATAS TANAH DALAM PERSPEKTIF HUKUM PERTANAHAN
}

\author{
Supriyadi \\ Badan Pertanahan Nasional Mataram \\ Jalan Pariwisata No. 61 Mataram \\ Email: doctor_supriyadi@yahoo.co.id
}

\begin{abstract}
This research is motivated by the practice of buying and selling land rights with is preceded by a treaty called the Sale and Purchase Fastenings Agreement of Land Rights. The agreement is a pre-agreement before the implementation of sale and purchase of land rights. The issue raised is whether such agreements are acceptable in land laws. This paper is intended to obtain answers to these problems, and therefore could be used to form a more explicit legal norms regarding the Sale and Purchase Fastenings Agreement of Land Rights. This is a normative legal research using the conceptual approach and statute approach. The results shows that that: First, the legal position of the Sale and Purchase Fastenings Agreement of Land Rights can be accepted as the law of life in the practice of the people of Indonesia, as well as to fill the void of legal norms. Secondly, payment of the price of the Sale and Purchase Agreement Landrights does not result in the ownership of the land from the seller to the buyer, but only a downpayment or sign so. Third, legal protection for well-meaning potential buyers and has paid in the event of nullification agreement is given in the form of their absolute power and the clauses contained in the Sale and Purchase Fastenings Agreement of Land Rights.
\end{abstract}

Key words: legal position, binding agreement of sale, land rights, land law perspective

\begin{abstract}
Abstrak
Dilatarbelakangi oleh adanya praktik jual beli dengan objek hak atas tanah yang didahului dengan suatu perjanjian yang disebut dengan Perjanjian Pengikatan Jual Beli Hak atas Tanah (PPJB-HAT). PPJB-HAT merupakan suatu bentuk perjanjian sebelum dilaksanakannya jual beli hak atas tanah. Isu yang mengemuka kemudian, apakah perjanjian tersebut dapat diterima dalam hukum pertanahan. Tulisan ini dimaksudkan untuk memperoleh jawaban terhadap permasalahan tersebut dan selanjutnya dapat dipergunakan untuk membentuk norma hukum yang lebih eksplisit mengenai PPJB-HAT. Dengan metode hukum normatif dan menggunakan dua pendekatan, yaitu pendekatan konsep dan pendekatan perundang-undangan, diperoleh jawaban, bahwa: Pertama, kedudukan hukum PPJB-HAT dapat diterima sebagai hukum yang hidup dalam praktik masyarakat Indonesia, serta untuk mengisi kekosongan norma hukum. Kedua, pembayaran lunas terhadap harga dalam PPJB-HAT belum mengakibatkan beralihnya hak atas tanah dari penjual kepada pembeli, namun hanya merupakan panjar atau tanda jadi. Ketiga, perlindungan hukum bagi calon pembeli yang beritikat baik dan telah membayar lunas dalam hal terjadi kebatalan perjanjian diberikan dalam bentuk adanya kuasa mutlak dan klausula yang tercantum dalam PPJB-HAT.
\end{abstract}

Kata kunci: kedudukan hukum, perjanjian pengikatan jual-beli, hak atas tanah, perspektif hukum pertanahan. 


\section{Latar Belakang}

Undang Undang Nomor 5 Tahun 1960 tentang Peraturan Dasar Pokok Pokok Agraria (LN 1960 Nomor: 104, TLN Nomor 2043) yang dikenal dengan sebutan Undang Undang Pokok Agraria disingkat UUPA, mengamanatkan kepada pemerintah untuk menyelenggarakan Pendaftaran Tanah.

Berdasarkan amanat undang-undang tersebut selanjutnya terbit Peraturan Pemerintah Nomor 10 Tahun 1961 tentang Pendaftaran Tanah dan kemudian Peraturan Pemerintah tersebut dicabut dengan Peraturan Pemerintah Nomor 24 Tahun 1997 tentang Pendaftaran Tanah (LNRI Tahun 1997 Nomor 59; TLNRI Nomor 3696).

Salah satu hal yang diatur dalam Peraturan Pemerintah Nomor 24 Tahun 1997 ialah ditetapkannya jabatan Pejabat Pembuat Akta Tanah yang diberi kewenangan untuk membuat alat bukti mengenai perbuatan hukum tertentu mengenai hak atas tanah dan Hak Milik Atas Satuan Rumah Susun. Alat bukti dimaksud selanjutnya akan dijadikan sebagai dasar pendaftaran tanah, baik pendaftaran tanah pertama kali maupun pemeliharaan data pendaftaran tanah.

Pasal 7 Peraturan Pemerintah Nomor 24 Tahun 1997 menentukan bahwa mengenai Pejabat Pembuat Akta Tanah, selanjutnya disebut PPAT, diatur dalam suatu Peraturan Pemerintah. Ketentuan Pasal 7 Peraturan Pemerintah Nomor 24 Tahun 1997 tersebut ditindaklanjuti dengan terbitnya Peraturan Pemerintah Nomor 37 Tahun 1998 Tentang Peraturan Jabatan Pejabat Pembuat Akta Tanah (Lembaran Negara Republik Indonesia Nomot Tahun 1998 Nomor 52, Tambahan Lembaran Negara Republik Indonesia Nomor 3746) juncto Peraturan Pemerintah Republik Indonesia Nomor 24 Tahun 2016 Tentang Perubahan Atas Peraturan Pemerintah Nomor 37 Tahun 1998 Tentang Peraturan Jabatan Pejabat Pembuat Akta Tanah (Lembaran Negara Republik Indonesia Tahun 2016 Nomor 120, Tambahan Lembaran Negara Republik Indonesia Nomor 5893), selanjutnya disebut Peraturan Jabatan PPAT

PPAT melaksanakan tugas pokok atas sebagian kegiatan pendaftaran tanah dengan membuat akta sebagai bukti mengenai telah dilakukannya perbuatan hukum tertentu mengenai hak atas tanah atau Hak Milik Atas Satuan Rumah Susun. Perbuatan hukum dimaksud yaitu: jual beli, tukar-menukar, hibah, pemasukan ke dalam perusahaan (inbreng), pembagian hak bersama, pemberian Hak Guna Bangunan/Hak Pakai atas Tanah Hak MIlik, Pemberian Hak Tanggungan, dan Pemberian Kuasa Membebankan Hak Tanggungan.

Dalam praktik jual beli dengan objek hak atas tanah didahului dengan suatu perjanjian yang disebut dengan Perjanjian Pengikatan Jual Beli atau yang dalam istilah praktik disebut PPJB, dan dalam hal ini disebut PPJB-HAT. 
R. Subekti ${ }^{1}$ menyatakan, bahwa perjanjian pengikatan jual beli adalah perjanjian antar pihak penjual dan pihak pembeli sebelum dilaksanakannya jual beli dikarenakan adanya unsur-unsur yang harus dipenuhi untuk jual beli tersebut, antara lain sertifikat hak atas tanah belum ada karena masih dalam proses, atau belum terjadinya pelunasan harga atau pajak-pajak yang dikenakan terhadap jual beli hak atas tanah belum dapat dibayar baik oleh penjual atau pembeli.

Sesuai pendapat tersebut di atas, pengikatan jual beli adalah suatu bentuk perjanjian sebelum dilaksanakannya jual beli hak atas tanah. Isu yang mengemuka kemudian, apakah perjanjian tersebut dapat diterima dalam hukum pertanahan.

Pasal 37 ayat (1) Peraturan Pemerintah Nomor 24 Tahun 1997 menyatakan bahwa:

"Peralihan hak atas tanah dan hak milik atas satuan rumah susun melalui jual beli, tukar-menukar, hibah, pemasukan dalam perusahaan dan perbuatan hukum pemindahan hak lainnya, kecuali pemindahan hak melalui lelang hanya dapat didaftarkan jika dibuktikan dengan akta yang dibuat oleh PPAT yang berwenang menurut ketentuan peraturan perundang-undangan yang berlaku".

Ketentuan Pasal 37 ayat (1) Peraturan Pemerintah Nomor 24 Tahun 1997 tersebut sesungguhnya tidak menentukan mengenai sah atau tidaknya serta terjadinya suatu peralihan hak atas tanah, misalnya melalui jual beli, tetapi mengatur mengenai pendaftaran peralihan haknya. Artinya, bahwa mengenai sah atau tidaknya serta terjadinya suatu perbuatan hukum peralihan hak atas tanah tidak tergantung dari ada atau tidak adanya akta PPAT tersebut, serta dilakukan dan/atau tidak dilakukan dihadapan PPAT.

Hal tersebut tampak dalam ketentuan Pasal 37 ayat (2) yang menyatakan, bahwa:

"Dalam keadaan tertentu
sebagaimana yang ditentukan oleh
Menteri, Kepala Kantor Pertanahan
dapat mendaftar pemindahan
hak atas bidang tanah hak milik,
dilakukandiantara perorangan warga
negara Indonesia yang dibuktikan
dengan akta yang tidak dibuat oleh
PPAT, tetapi yang menurut Kepala
Kantor Pertanahan tersebut kadar
kebenarannya dianggap cukup untuk
mendaftar pemindahan hak yang
bersangkutan".

Sampai saat ini pun belum ada peraturan perundang-undangan yang mengatur tentang syarat-syarat sahnya perjanjian jual beli hak atas tanah di Indonesia. Hal ini berbeda dengan Kitab Undang Undang Hukum Perdata (KUH Perdata) yang mengatur tentang syarat-syarat sahnya suatu perjanjian. Isu yang mengemuka selanjutnya, apakah dengan demikian syaratsyarat sahnya perjanjian sebagaimana tertuang dalam Pasal 1320 KUH Perdata dapat diberlakukan untuk sahnya suatu perjanjian jual beli hak atas tanah.

Pasal 5 UUPA menyatakan:

"Hukum Agraria yang berlaku atas bumi, air dan ruang angkasa

1 R. Subekti, Aspek-Aspek Hukum Perikatan Nasional, (Bandung: Citra Aditya Bakti, 1998), hlm. 29. 
ialah hukum adat, sepanjang tidak bertentangan dengan kepentingan nasional dan Negara, yang berdasarkan persatuan bangsa, dengan sosialisme Indonesia serta dengan peraturan-peraturan yang tercantum dalam Undang-undang ini dan dengan peraturan perundangan lainnya, segala sesuatu dengan mengindahkan unsur-unsur yang bersandar pada hukum agama".

Mencermati ketentuan Pasal 5 UUPA tersebut, pemberlakukan hukum adat dimaksud tidaklah bersifat mutlak, namun dengan empat persyaratan sebagaimana dimaksud dalam ketentuan Pasal 5 UUPA. Hal ini selanjutnya akan menimbulkan suatu pertanyaan, apakah dalam perjanjian peralihan hak atas tanah melalui jual beli berlaku hukum adat? Hukum adat manakah yang dipakai? Pertanyaan ini perlu dikemukakan mengingat Penjelasan Umum III angka (1) UUPA terkait dengan hukum adat sebagaimana dimaksud pada Pasal 5 UUPA masih bersifat umum dan belum mampu menjawab persoalan jual beli hak atas tanah yang bersifat lebih khusus. ${ }^{2}$

Apabila yang dimaksud dengan hukum adat dalam hal ini adalah prinsip-prinsip atau azas-azas yang dianut dalam jual beli menurut hukum adat, yaitu bersifat tunai, riil dan terang, maka dalam hal perjanjian yang telah memenuhi syarat tunai, riil dan terang namun dalam praktiknya dituangkan dalam suatu perjanjian pengikatan jual beli dengan akta notariil, apakah hal ini dapat diterima dalam hukum pertanahan, karena keduanya merupakan hal yang kontradiktif.

Di sisi yang lain, telah diundangkan Undang-undang Nomor 30 Tahun 2004 (Lembaran Negara Republik Indonesia Tahun 2004 Nomor 117, Tambahan Lembaran Negara Republik Indonesia Nomor 4432) tentang Jabatan Notaris juncto UndangUndang Republik Indonesia Nomor 2 Tahun 2014 tentang Perubahan Atas Undang-undang Nomor 30 Tahun 2004 tentang Jabatan Notaris (Lembaran Negara Republik Indonesia Tahun 2014 Nomor 3, Tambahan Lembaran Negara Republik Indonesia Nomor 5491), selanjutnya disebut UUJN.

Undang-undang ini dimaksudkan untuk menjamin kepastian, ketertiban, dan perlindungan hukum berdasarkan alat bukti tertulis dalam bentuk akta otentik mengenai keadaan, peristiwa, atau perbuatan hukum yang dilakukan melalui jabatan notaris.

Pasal 15 ayat (2) huruf $\mathrm{f}$ UUJN menyatakan, bahwa notaris berwenang membuat akta yang berkaitan dengan pertanahan. Persoalan yang mengemuka

2 Penjelasan Umum III angka (1) menyatakan:

„,... Dengan sendirinya hukum agraria baru itu harus sesuai dengan kesadaran hukum daripada rakyat banyak. Oleh karena rakyat Indonesia sebagain besar tunduk pada hukum adat, maka hukum agraria yang baru tersebut akan didasarkan pula pada ketentuan-ketentuan hukum adat itu, sebagi hukum asli, yang disempurnakan dan disesuaikan dengan kepentingan masyarakat dalam Negara yang modern dan dalam hubungannya dengan dunia internasional, serta disesuaikan dengan Sosialisme Indonesia. Sebagaimana dimaklumi maka hukum adat dalam pertumbuhannya tidak terlepas pula dari pengaruh politik dan masyarakat kolonial yang kapitalistis dan masyarakat swapraja yang feodal“6. 
kemudian, apakah ketentuan tersebut tidak bertentangan dengan ketentuan Pasal 37 ayat (1) Peraturan Pemerintah Nomor 24 Tahun 1997? atau justru ketentuan Pasal 15 ayat (2) huruf f Undang Undang Jabatan Notaris dapat diterima sebagaimana dimaksud ketentuan Pasal 37 ayat (2) Peraturan Pemerintah Nomor 24 Tahun 1997.

\section{Eksistensi Pasal 15 ayat (2) Undang} Undang Jabatan Notaris semestinya harus dipandang sebagai norma hukum yang memberikan dasar bagi perjanjian pendahuluan peralihan hak atas tanah yang merupakan pengembangan hukum pertanahan sebagaimana dimaksud Penjelasan Umum III angka (1) UUPA, yang intinya bahwa hukum pertanahan dibangun berdasarkan hukum adat yang disempurnakan dan disesuaikan dengan kepentingan masyarakat dalam Negara yang modern, sehingga dengan demikian eksistensi Pasal 15 ayat (2) Undang Undang Jabatan Notaris tidak bertentangan dengan Pasal 37 ayat (1) dan (2) Peraturan Pemerintah Nomor 24 Tahun 1997. ${ }^{3}$

\section{Pembahasan}

\section{A. Kedudukan Perjanjian Pengikatan Jual Beli Hak atas Tanah
1. Menurut konsep Kitab Undang- undang Hukum Perdata (KUH Perdata)

Buku II Kitab Undang Undang Hukum Perdata (KUH Perdata/ $B W$ ) telah dinyatakan dicabut dan tidak berlaku sepanjang mengenai bumi, air serta kekayaan alam yang terkandung di dalamnya bersamaan dengan diberlakukannnya UUPA. Namun demikian, Buku III KUH Perdata $(B W)$ tidak secara tegas dinyatakan tidak berlaku. Terhadap hal ini harus dipandang bahwa norma hukum dalam Buku III KUH Perdata yang tidak secara tegas dinyatakan tidak berlaku tersebut, setidaknya merupakan konsep hukum sepanjang tidak bertentangan dengan prinsip-prinsip hukum agraria, disamping kenyataannya belum tersedia hukum positif mengenai perbuatanperbuatan hukum hak atas tanah. ${ }^{4}$

3 Alfiansyah, "Urgensi Perjanjian Pengikatan Jual Beli (PPJB) Hak Atas Tanah Yang Dibuat Oleh Notaris", http:/hukum.studentjournal.ub.ac.id/index.php/hukum/article/view/1322, diakses 11 Januari 2017. Hasil penelitian oleh Alfiansyah, antara lain bahwa, pentingnya aturan yang ditetapkan pemerintah untuk mengatur secara khusus akta perjanjian pengikatan jual beli agar bentuk akta yang dibuat oleh notaris dapat memberikan kepastian dan perlindungan hukum.

4 Peraturan Pemerintah Nomor 24 Tahun 1997 tentang Pendaftaran Tanah jo. Peraturan Menteri Negara Agraria/Kepala Badan Pertanahan Nasional Nomor 3 Tahun 1997 tentang Peraturan Pelaksanaan Pertauran Pemerintah Nomor 24 Tahun 1997 tentang Pendaftaran Tanah, hanya menyebutkan, bahwa peralihan hak atas tanah dan hak milik atas satuan rumah susun melalui jual-beli, tukar-menukar, hibah, pemasukan dalam perusahaan, dan perbuatan hukum pemindahan hak lainnya, kecuali pemindahan hak melalui lelang hanya dapat didaftarkan jika dibuktikan dengan akta yang dibuat oleh PPAT yang berwenang menurut ketentuan peraturan perundang-undangan yang berlaku. Namun demikian, bagaimana syarat-syarat, saat terjadinya, dan kebatalan peralihan atau pemindahan hak atas tanah tidak diatur dalam dua peraturan perundang-undangan tersebut, sehingga terdapat kekosongan norma hukum. 
Perjanjian Pengikatan Jual Beli Hak Atas Tanah, selanjutnya disingkat PPJB-HAT, merupakan suatu perjanjian antara 'calon' pembeli dan 'calon' penjual dengan obyek hak atas tanah. Hak atas tanah sebagai obyek jual beli dapat berupa Hak Milik, Hak Guna Usaha, Hak Guna Bangunan atau Hak Pakai.

PPJB-HAT yang dimaksud dalam tulisan ini ialah PPJB HAT dengan pembayaran lunas yang dibuat bersama dengan Kuasa menjual dan pada umumnya dibuat dengan akta notariil, ${ }^{5}$ yaitu akta pihak (partij akta) berdasarkan asas kebebasan berkontrak sebagaimana diatur dalam ketentuan pasal 1338 KUH Perdata, bahwa semua perjanjian yang dibuat secara sah berlaku sebagai undang-undang bagi para pihak yang membuatnya. Suatu perjanjian tidak dapat ditarik kembali selain dengan kesepakatan kedua belah pihak, atau karena alasan-alasan yang oleh undang-undang dinyatakan cukup untuk itu. Suatu perjanjian harus dilaksanakan dengan itikad baik. Konsep hukum demikian itu sesungguhnya tidak bertentangan dan dapat diterima terhadap perjanjian dengan objek hak atas tanah.

Pasal 1319 KUH Perdata menyatakan, bahwa semua perjanjian, baik yang mempunyai nama khusus, maupun yang tidak dikenal dengan suatu nama tertentu, tunduk pada peraturan-peraturan umum, yang termuat dalam bab ini maupun bab yang lalu. Bab ini yang dimaksudkan dalam frasa tersebut adalah
Buku III BAB KEDUA Tentang perikatanperikatan yang dilahirkan dari kontrak dan perjanjian, sedangkan yang dimaksud dengan bab yang lalu ialah Buku III BAB KESATU Tentang perikatan-perikatan umumnya. PPJB-HAT termasuk dalam perjanjian tanpa nama, karena tidak secara khusus disebut dalam KUH Perdata seperti misalnya jual beli, sewa menyewa dan lain-lain, sehingga tunduk pada azas-azas umum perjanjian.

Dalam membuat akta PPJB-HAT notaris bersandar pada ketentuan Pasal 15 ayat (2) huruf f UUJN yang memberikan kewenangan kepada notaris untuk membuat akta yang berkaitan dengan pertanahan. Tulisan ini tidak hendak menguji apakah ketentuan Pasal 15 ayat (2) huruf $f$ UUJN tersebut bertentangan dengan norma lainnya yang mengatur tentang pertanahan, sehingga keberadaan Pasal 15 ayat (2) huruf f UUJN harus difahami sedemikian adanya sebagai dasar bagi notaris untuk membuat akta PPJB-HAT dan secara normatif diterima sedemikian rupa sebagai norma yang berlaku sebagai hukum positif.

Ketentuan Pasal 15 ayat (2) huruf f UUJN tersebut sekaligus menjawab pendapat Sri Soedewi Masjchoen Sofwan yang menyatakan:

"Dengan dicabutnya Buku II KUH Perdata, maka pasal-pasal yang merupakan ataupun bertalian dengan pasal-pasal yang tak berlaku itu, meskipun tidak tegas-tegas dicabut dan diletakkan di luar buku II, Buku

5 PPJB-HAT tidak ada aturan khusus yang menyebutkan harus dibuat dengan akta notariil. PPJB-HAT juga masih dapat memenuhi ketentuan Pasal 1320 BW walaupun dibuat dengan Surat Di Bawah Tangan. 
III, Buku IV KUH Perdata juga dianggap tidak berlaku lagi,... ${ }^{6}$ Juga pasal-pasal tentang sewa menyewa, jual beli tanah dan lain-lain, karena bertalian dengan tanah yang sudah diatur khusus dalam UUPA maka pasal-pasal tersebut tak berlaku lagi. $^{7}$

Dengan tetap menghormati pendapat tersebut, persoalan yang mengemuka ialah bagaimana jika terdapat kekosongan hukum untuk mengatur peralihan hak atas tanah, karena sampai saat inibelum terdapat peraturan perundang-undangan yang mengatur tentang perbuatan-perbuatan hukum atas tanah, misalnya: apa dan bagaimana syarat dan sahnya serta kebatalan jual beli, tukar-menukar, hibah, sewa-menyewa dan perbuatan hukum hak atas tanah lainnya. Dinyatakan terdapat kekosongan norma hukum, karena Buku II KUH Perdata yang berkaitan dengan bumi, air serta kekayaan alam yang terkandung di dalamnya secara tegas dinyatakan dicabut oleh UUPA, sehingga Buku III yang berkaitan dengan agraria tersebut juga tidak berlaku. Interpretasi demikian sangat logis, karena hal-hal yang diatur sebagimana tercantum dalam Buku II KUH Perdata sudah tidak ada, maka Buku III yang berkaitan dengan hal-hal yang sudah tidak ada itu menjadi tidak relevan.

Namun demikian, demi mengisi kekosongan norma hukum sebagai dijelaskan di atas, maka pasal-pasal pada Buku III KUH Perdata yang berkaitan dengan pengaturan agraria dapat tetap menjadi sebuah konsep hukum yang digunakan untuk mengisi kekosongan norma hukum dimaksud, karena hal ini menyangkut hal yang urgen berupa praktik transaksi keseharian masyarakat terhadap objek berupa hak atas tanah.

Pasal 5 UUPA memang telah mengatur, bahwa hukum agraria yang berlaku atas bumi, air dan ruang angkasa ialah hukum adat. Pertanyaan yang mengemuka selanjutnya ialah, hukum adat yang mana. Apakah hukum adat yang bersifat tunai, nyata/ riil, dan terang. Jika hukum adat demikian itu yang dimaksudkan, kemudian mengapa peralihan hak atas tanah harus dilakukan di hadapan PPAT. Persoalan-persoalan tersebut mengemuka tidak lain karena terdapat kekososngan hukum.

Untuk mengisi kekosongan hukum itulah maka pemberlakukan konsep hukum perikatan sebagaimana termaktub dalam Buku III KUH Perdata dan prinsip-prinsip hukum adat yang masih relevan dapat diberlakukan lagi untuk menilai sah tidaknya peralihan hak atas tanah, sebagai hukum yang hidup dalam masyarakat.

Mencermati substansi akta PPJB-HAT pada umumnya, senantiasa memuat klausul, sebagai berikut:

1. Komparan: PIHAK PERTAMA selalu disebut sebagai PENJUAL dan PIHAK KEDUA selalu disebut sebagai PEMBELI.

6 Sri Soedewi Masjchoen Sofwan, Hukum Perdata: Hukum Benda, (Yogyakarta: Liberty, 1975), hlm. 7.

7 Ibid. 
2. Premis Akta: PIHAK PERTAMA dengan ini menyatakan dan mengikatkan diri untuk bersama-sama dengan PIHAK KEDUA melangsungkan penjualan/ pembelian tanah tersebut dihadapan Pejabat yang dimaksud dalam Peraturan Pemerintah Nomor 24 Tahun 1997 tentang Pendaftaran Tanah.

Pertanyaan yang mengemuka, mengapa Notaris tidak menulis dalam PPJB bahwa PIHAK PERTAMA sebagai CALON PENJUAL dan PIHAK KEDUA sebagai CALON PEMBELI. Hal ini terjadi karena sifat konsensuil dalam perjanjian sebagaimana diatur dalam Buku III KUH Perdata. Secara materiil PPJB-HAT telah melahirkan peralihan hak atas tanah seketika terjadi kata sepakat berdasarkan PPJB-HAT, walaupun harganya belum dibayar lunas dan barangnya belum diserahkan. Namun demikian, dalam hal objek perjanjian berupa hak atas tanah semestinya notaris harus memberi sebutan kepada para pihak, masing-masing sebagai Calon Penjual dan Calon Pembeli, karena secara formal terjadinya jual beli hak atas tanah akan dilangsungkan dihadapan PPAT sebagaimana diatur dalam Peraturan Pemerintah Nomor 24 Tahun 1997 tentang Pendaftaran Tanah jo. Peraturan Pemerintah Nomor 38 Tahun 1997 tentang Pejabat Pembuat Akta Tanah.

Dalam kaitan tersebut di atas, selanjutnya dapat dicermati ketentuan KUH Perdata yang mengatur tentang uang panjar. Pasal 1464 KUH Perdata menyatakan:

"Jika pembelian dibuat dengan memberi uang panjar tak dapatlah salah satu pihak meniadakan pembelian itu dengan menyuruh memiliki atau mengembalikan uang panjarnya".

Ketentuan Pasal 1454 KUH Perdata memberikan pemahaman, bahwa jual-beli yang didahului dengan panjar tidak dapat dibatalkan. Hal ini sesuai dengan sifat konsensuil dalam perjanjian berdasarkan KUH Perdata, karena dengan adanya panjar sesungguhnya telah terjadi konsensus antara calon pembeli dan penjual, sehingga jual-beli telah terjadi. Hal ini berbeda dengan hukum adat yang bersifat riil.

Mengenai sifat konsensuil perjanjian tersebut lebih tegas dapat disimak ketentuan Pasal 1458 KUH Perdata, bahwa "Jual-beli itu dianggap telah terjadi antara kedua belah pihak, seketika setelahnya orang-orang ini mencapai sepakat tentang kebendaan tersebut dan harganya, meskipun kebendaan itu belum diserahkan, maupun harganya belum dibayar".

Pasal 1459 KUH Perdata: "Hak milik atas barang yang dijual tidaklah berpindah kepada si pembeli, selama penyerahannya belum dilakukan menurut Pasal 612, 613,dan 616”.

Berdasarkan analisis tersebut di atas, pembayaran harga baik sebagian maupun lunas dalam PPJB dapat dikategorikan 
sebagai uang panjar. ${ }^{8}$ Hal ini untuk mengisi kekosongan hukum, karena dalam Peraturan Pemerintah Nomor 37 Tahun 1998 tentang Pejabat Pembuat Akta Tanah belum atau tidak mengatur mengenai hal ini. Dalam cakupan yang lebih luas dikatakan, bahwa hukum pertanahan belum mengatur secara komprehensif mengenai perjanjian hak atas tanah.

Pertanyaan yang mengemuka, bagaimana dengan ketentuan Pasal 5 UUPA, bahwa:

"Hukum agraria yang berlaku atas bumi, air dan ruang angkasa ialah hukum adat sepanjang tidak bertentangan dengan kepentingan nasional dan Negara, yang berdasarkan atas persatuan bangsa, dengan Sosialisme Indonesia serta dengan peraturan-peraturan yang tercantum dalam Undang-undang ini dan dengan peraturan-perundangan lainnya, segala sesuatu dengan mengindahkan unsur-unsur yang bersandar pada hukum agama".

Apakah PPJB-HAT yang eksistensinya bersandar pada norma-norma yang diatur dalam KUH Perdata tersebut tidak bertentangan dengan Hukum Pertanahan yang berdasarkan Hukum Adat.

Perlu ditegaskan kembali, bahwa sesungguhnya PPJB-HAT berdasarkan konsep KUH Perdata tidak bertentangan dan dapat diterima dalam hukum pertanahan berdasarkan hukum Adat sebagaimana dimaksud Pasal 5 UUPA, yang intinya bahwa hukum pertanahan dibangun berdasarkan hukum adat yang disempurnakan dan disesuaikan dengan kepentingan masyarakat dalam Negara yang modern (Penjelasan Umum III angka (1) UUPA).

\section{Menurut konsep hukum adat}

Hilman Hadikusuma ${ }^{9}$ menjelaskan, sebagai berikut:

"Menurut hukum adat suatu perjanjian dapat terjadi antara dua pihak yang saling berjanji atau dikarenakan sifatnya dianggap ada perjanjian. Suatu perjanjian belum tentu akan terus mengikat para pihak walaupun sudah disepakati. Agar suatu perjanjian yang disepakati dapat mengikat harus ada tanda ikatan. Tetapi dengan adanya tanda ikatan belum tentu suatu perjanjian itu dapat dipenuhi. Jadi suatu tanda ikatan menurut hukum adat belum

8 Bandingkan dengan pendapat Saleh Adiwinata dalam Pengertian Hukum Adat menurut Undang Undang Pokok Agraria, (Bandung: Alumni, 1976), hlm. 32-33: "Bilamana kita perhatikan jual-beli menurut UUPA ini dengan membadingkan caranya dengan jual-beli menurut hukum adat sebelum UUPA berlaku, maka dari saat terjadinya persetujuan jual beli sampai kepada si pembeli menjadi milik "penuh" adalah berbeda sekali. Caranya beserta formalitas-formalitas lainnya adalah lebih mirip kepada jual beli tanah eigendom dahulu daripada jual-beli tanah dengan hak milik Indonesia:

a Sistim panjer tidak dikenal lagi;

b Pejabat-pejabat hukum adat (Kepala persekutuan/desa) diganti dengan pejabat yang ditunjuk Menteri. Bahkan yang ditunjuk justru adalah para notaris yang tugasnya membuat akta-akta di lapangan hukum Eropa, disamping para camat dimana tidak terdapat notaris;

c Bentuk persetujan jual-belinya sudah ditentukan oleh Pemerintah yang boleh disebut "standard contract".

d Sanksi terhadap pelanggaran ini ditetapkan dengan tegas (pidana);

e Adanya keharusan untuk mendaftar tanah yang telah dibelinya itu;

f Adanya keharusan mempunyai sertipikat tanah dari Kantor Pendaftaran Tanah (Kantor Pertanahan: Penulis) guna kepentingan hukum bagi si pemiliknya.

9 Hilman Hadikusuma, Hukum Perjanjian Adat, (Bandung: Alumni, 1982), hlm. 103. 
tentu merupakan 'tanda pengikat'. Disamping itu terdapat tanda-tanda ikatan antara manusia dan bukan manusia. Dengan catatan tidak semua daerah di Indonesia berlaku tanda ikatan yang sama".

Dalam kaitan dengan PPJB-HAT, maka sesungguhnya PPJB-HAT dan konsep hukum Adat demikian itu merupakan dua hal yang identik. PPJB-HAT sesungguhnya merupakan tanda pengikat atau perjanjian pengikatan, walaupun pada PPJB-HAT tanda ikatan senantiasa berupa uang muka atau voorschot.

Dalam hukum perjanjian adat dikenal apa yang disebut dengan 'tanda akan jadi', yaitu tanda pengikat dari suatu perjanjian yang telah disepakati oleh kedua belah pihak, sehingga kedua belah pihak berkewajiban memenuhi perjanjian yang telah disepakti tersebut. Istilah yang popular untuk 'tanda akan jadi' tersebut disebut 'panjer' (Jawa). ${ }^{10}$ Hingga saat ini tetap sama dan berlaku.

Transaksi tanah yang bersifat perbuatan hukum dua pihak tersebut disebut sebagai perbuatan hukum bersegi dua (tweezijdig). Inti dari transaksi tersebut adalah peralihan hak atas tanah disertai dengan pembayaran kontan dari pihak lain seketika. Dalam hukum tanah, perbuatan hukum tersebut disebut transaksi jual (Adol: Bahasa Jawa/ Sade: Bahasa Jawa Tinggi). Transaksi jual menurut isinya dibedakan menjadi tiga macam, yaitu: ${ }^{11}$ a. Penyerahan tanah dengan pembayaran kontan disertai dengan ketentuan bahwa yang menyerahkabn tanah mempunyai hak untuk mengambil kembali tanah dimaksud dengan pembayaran uang yang sama jumlahnya (Jual Gadai, Manggadai: Minangkabau), Adol/Sende (Jawa), Ngajual Akad/Ngajual Gade (Sunda), Menjual Gadai (Riau dan Jambi).

b. Penyerahan tanah dan pembayaran kontan tanpa syarat, untuk seterusnya dan selamanya. (Adol Plas: Jawa; Menjual Jada: Kalimantan; Menjual Lepas: Riau dan Jambi)

c. Penyerahan tanah dengan pembayaran kontan disertai perjanjian bahwa apabila kemudian tidak ada perbuatan hukum lain sesudah satu atau dua atau tiga atau beberapa kali panen, tanah tersebut kembali kepada pemilik tanah semula. (Menjual Tahunan, Adol Ayodan (Jawa).

Menurut Saleh Adiwinata, ${ }^{12}$ ketentuan ketentuan tentang jual-beli tanah serta keharusannya untuk membuat akta jual-beli tanah tersebut dihadapan PPAT merupakan ketentuan yang memaksa (dwigende recht), karena pada jual-beli dan transaksi-transaksi lainnya terkait dengan tugas pengawasan terhadap transaksi-transaksi tersebut oleh Pemerintah. Selanjutnya dinyatakan, bahwa sekalipun dapat dianggap hak atas tanah sudah beralih, namun peralihan itu belum berlaku bagi pihak ketiga. Meskipun si pembeli sudah mempunyai akta PPAT, tidak boleh menjual

10 Ibid., hlm. 106.

11 Tolib Setiady, Intisari Hukum Adat Indonesia-Dalam Kajian Kepustakaan, (Bandung: Alfabeta, 2008), hlm. 325-329.

12 Saleh Adiwinata, Pengertian Hukum Adat Menurut Undang Undang Pokok Agraria, (Bandung: Alumni, 1976), hlm. 29-42. 
kembali hak tanah tersebut kepada pihak ketiga, selama belum dibalik nama di Kantor Pertanahan.

Selanjutnya simak pendapat Saleh Adiwinata ${ }^{13}$, sebagai berikut:

"Bilakah terjadinya peralihan hak pada jual beli tanah menurut Undang-undang Pokok Agraria? Sebagaimana dikatakan di atas, soal saat peralihan hak pada jual beli tanah dalam hukum adat sebelum berlakunya Undang-undang tersebut, tidak terjadi persoalan yaitu berkat adanya prinsip 'gelijke oversteken', maka serentak tanah itu beralih pada waktu akta jualbelinya ditandatangani dihadapan Kepala Desa. Pada jual-beli tanah menurut UUPA, hal ini dapat menjadi persoalan. Tidak mungkin kiranya bilamana kita anggap hak itu pindah kepada si pembeli pada waktu akta yang dibuat dihapan Pejabat Pembuat Akta Tanah (PPAT) ditandatangani oleh para fihak yang bersangkutan, sebab peralihan hak miliknya itu masih harus disetujui dulu oleh Menteri Agraria atau atau pejabat yang ditunjuk olehnya..."

Tafsiran Pengertian "Hukum Adat" dalam UUPA sebagai Hukum Adat yang masih Bersifat Kontan (Hukum Adat Murni) tidak memadai. Budi Harsono dalam membicarakan peralihan hak kepada si pembeli, berpendapat bahwa saat itu terjadi pada waktu dilakukanjual beli di hadapan Pejabat Pembuat Akta Tanah berdasarkan pasal 5 UUPA, yang menentukan, bahwa hukum agraria dalam UUPA ini adalah hukum adat. Hukum adat yang disebut dalam pasal 5 UUPA ini olehnya ditafsirkan sebagai hukum adat yang sistimnya masih konkrit/ kontan/tunai. Hal ini dapat kami simpulkan dari kata-kata beliau sebagai berikut: "Kalau kita berpegang pada sifat tunai daripada jual-beli, sifat mana dianggap ada pada jualbeli tanah menurut hukum agraria sekarang berdasar atas ketentuan pasal 5 UUPA, maka kiranya jawabannya tidak bisa lain daripada bahwa pada saat dilakukannya jual beli dihadapan PPAT itulah haknya beralih kepada pembeli".

Tafsiran ini, menurut hemat kami tidak tepat disebabkan beberapa alasan:

a. Suatu kenyataan ialah bahwa UUPA ini sudah dipakai untuk merubah ketentuanketentuan dalam KUHS terutama buku II. Kita tahu bahwa KUHS menganut sistim hukum yang abstrak/konsensuil. Bilamana kita tafsirkan hukum adat yang menjadi dasar dari seluruh ketentuanketentuan UUPA sebagai suatu sistim hukum yang konkrit/kontan/tunai, hal ini akan bertentangan dengan nasihatnasihat dari para ahli hukum adat yang kami sajikan di atas;

b. Tuntutan zaman modern membutuhkan suatu sistem hukum yang abstrak/ konsensuil (lihat di atas tentang lembaga crediet);

c. Praktik pengadilan sehari-hari sudah tidak memakai lagi sistem hukum yang kontan/tunai dalam perkara-perkara 
perdata antara orang-orang Indonesia asli;

d. Beberapa tujuan pokok daripada UUPA tidak akan tercapai antara lain:

1. Kesederhanaan dalam hukum pertanahan,

2. Kepastian hukum bagi si pembeli tanah.

e. Akan timbul konstruksi-konstruksi hukum yang menyimpang daripada ajaran-ajaran umum dalam ilmu hukum.

Berdasarkan pendapat-pendapat dari dua ahli Hukum Agraria masing-masing Saleh Adiwinata dan Boedi Harsono mengenai hukum adat yang dimaksud dalam ketentuan Pasal 5 UUPA, serta saat terjadinya peralihan hak atas tanah, maka terdapat perbedaan pendapat, sebagai berikut: Pertama, dalam hal hukum adat, Saleh Adiwinata berpendapat, bahwa hukum adat bukan lagi bersifat konkrit/ kontan/tunai, sedangkan Boedi Harsono berpendapat konkrit/kontan/tunai. Kedua, dalam hal saat terjadinya peralihan hak atas tanah, Saleh Adiwinata berpendapat pada saat dilakukan pendaftaran tanah atau balik nama, sedangkan Boedi Harsono berpendapat pada saat ditandatanganinya Akta PPAT.

Penulis sependapat dengan Saleh Adiwinata dalam dua persoalan tersebut di atas dengan suatu argumentasi, bahwa ketentuan Pasal 5 UUPA semestinya tidak dibaca kata per kata atau frasa demi frasa melainkan harus dibaca sebagai satu kalimat secara keseluruhan, sehingga makna yang diperoleh akan lebih sempurna. Hukum adat yang berlaku bagi Hukum Agraria yang berlaku atas bumi, air dan ruang angkasa ialah hukum adat yang: (i) tidak bertentangan dengan kepentingan nasional dan Negara; (ii) berdasarkan atas persatuan bangsa, dengan Sosialisme Indonesia; (iii) berdasarkan peraturan-peraturan yang tercantum dalam Undang-undang Pokok Agraria dan dengan peraturan-perundangan lainnya; mengindahkan unsur-unsur yang bersandar pada hukum agama".

Dengan analisis demikian itu, maka apabila hukum adat sebagaimana dimaksud pada Pasal 5 Undang Undang Pokok Agraria bersifat tunai, riil, dan terang, tentunya keberadaan PPAT dengan tugas dan kewenangannya tidak perlu seperti saat ini. Keberadaan PPAT dengan tugas dan kewenangannya saat ini justru menunjukkan tugas dan kewenangan pengembanan hukum adat yang modern agar mampu mengikuti perkembangan transaksi dan perbuatan-perbuatan hukum atas tanah.

\section{Dalam perspektif hukum pertanahan}

Hukum Pertanahan yang dimaksudkan adalah berbagai peraturan perundangundangan yang mengatur tentang penguasaan, pemilikan, penggunaan dan pemanfaatan tanah. Dalam kaitannya dengan permasalahan ini, lebih khusus hukum pertanahan yang dimaksudkan adalah peraturan perundangundangan yang berkaitan dengan perjanjian dengan obyek hak atas tanah.

Dari hasil inventarisasi dan penulusuran terhadap hukum pertanahan, tidak ditemukan 
adanya satu pun norma hukum yang jual beli tanah dan lain-lain yang bertalian mengatur tentang sahnya jual beli hak atas dengan tanah. Demikian pula peraturan tanah. Peraturan Pemerintah Nomor 24 perundang-undangan di bawah UUPA, belum Tahun 1997 tentang Pendaftaran Tanah hanya menentukan bahwa setiap peralihan hak atas tanah yang salah satunya berupa jual-beli harus dilakukan di hadapan PPAT, tetapi apa saja syarat-syarat jual beli, terjadinya jual beli, saat beralihnya hak atas tanah, dan lainlain belum diatur secara tegas dalam hukum pertanahan. Hal ini berbeda dengan KUH Perdata yang telah mengatur hal-hal berkaitan dengan pelaksanaan suatu jual beli.

Di sisi lain, KUH Perdata tidak dapat lagi digunakan sebagai dasar pengaturan jual-beli hak atas tanah. Dengan dicabutnya Buku II KUH Perdata hal-hal berkaitan bumi, air dan ruang angkasa, maka menurut Sri Soedewi Masjchoen Sofwan, pasal-pasal yang merupakan ataupun bertalian dengan pasalpasal yang tak berlaku itu, meskipun tidak tegas-tegas dicabut dan diletakkan di luar buku II, yaitu dalam Buku III, Buku IV KUH Perdata juga dianggap tidak berlaku lagi,... ${ }^{14}$ Juga pasal-pasal tentang sewa menyewa, jual beli tanah dan lain-lain, karena bertalian dengan tanah yang sudah diatur khusus dalam UUPA maka pasal-pasal tersebut tak berlaku lagi. ${ }^{15}$

Terhadap pendapat Sri Soedewi Masjchoen Sofwan tersebut dianalisis, sebagai berikut: Pertama, sesungguhnya UUPA belum mengatur tentang sewa-menyewa, ada satupun peraturan perundang-undangan yang mengatur tentang syarat, terjadinya dan batalnya serta hal-hal yang berkaitan dengan peralihan hak atas tanah. Kedua, terhadap PPJB-HAT yang telah dan sering terjadi dalam kehidupan transaksional masyarakat, sepanjang dilakukan dengan benar, maka dasar-dasar teoritik sesungguhnya telah ada dalam hukum adat yang eksistensi hukum adat itu sendiri juga diakui secara tegas oleh Pasal 5 UUPA sebagai dasar berlakunya hukum agraria.

UUPA sebagai undang-undang pokok yang mengatur tentang hal-hal mendasar mengenai agraria, termasuk pertanahan di dalamnya, hanya menentukan bahwa hukum yang berlaku bagi agraria adalah hukum adat. Artinya, bahwa pengaturan tentang penguasaan, pemilikan, penggunaan dan pemanfaatan tanah, termasuk peralihan hak atas tanah berdasarkan hukum adat.

Pertanyaan yang mengemuka kemudian, apakah pemberlakuan hukum adat tersebut merupakan satu-satunya hukum ataukah merupakan salah satu hukum, disamping hukum yang lain, misalnya hukum yang bersumber dari KUH Perdata? ataukah Hukum Adat yang dimaksud Pasal 5 UUPA tersebut merupakan prinsip-prinsip Hukum Adat, bukan norma Hukum Adat? Bagaimana 
dengan prinsip-prinsip hukum umum yang terkandung dalam KUH Perdata? Pertanyaanpertanyaan tersebut perlu memperoleh jawaban untuk memberikan kepastian hukum.

Mengenai hukum adat yang dimaksud dalam UUPA dapat disimak Penjelasan Umum

III UUPA yang menyatakan antara lain:

"Oleh karena rakyat Indonesia sebagian besar tunduk pada hukum adat, maka hukum agraria yang baru tersebut akan didasarkan pula pada ketentuan-ketentuan hukum adat itu, sebagai hukum yang asli, yang disempurnakan dan disesuaikan dengan kepentingan masyarakat dalam Negara yang modern dan dalam hubungannya dengan dunia internasional,...".

Dalam kaitan tersebut di atas, penting disimak pendapat Sunaryati Hartono, ${ }^{16}$ sebagai berikut:

"Jadi dalam proses perkembangan hukum baru tidak semua kaidah hukum baru bertentangan dengan hukum yang lama. Demikian pula tidak semua kaidah hukum nasional harus dan akan bertentangan dengan kaidah-kaidah hukum kolonial. Sebab dalam membina suatu masyarakat selalu ditemukan syarat-syarat dan nilai-nilai yang harus dipegang teguh oleh semua lingkungan masyarakat. Apalagi karena dalam proses perubahan dari hukum kolonial menjadi hukum nasional yang diatur itu adalah masyarakat Indonesia yang berdiri di kepulauan Nusantara juga, maka tidaklah mengherankan apabila nanti ada unsur-unsur yang sama dalam Hukum Nasional, yang sudah ada di dalam Hukum Adat ataupun di dalam hukum kolonial".

Berdasarkan penjelasan di atas, terdapat dua istilah yang digunakan. Penjelasan Umum III UUPA menggunakan kata 'ketentuanketentuan hukum adat", sedangkan Sunaryati Hartono menggunakan istilah 'unsur-unsur hukum adat'.

Sesuai penjelasan Sunaryati Hartono tersebut di atas, maka pemberlakuan hukum adat dalam mengatur agraria dalam arti luas dan pertanahan yang merupakan bagian dari agraria, lebih tepat jika difahami bahwa hukum adat sebagai salah satu dari hukum yang mengatur agraria, atau sebagai salah satu sumber hukum bagi pengaturan agraria dan bukan merupakan satu-satunya sumber hukum agraria.

Salah satu hukum pertanahan yang berlaku saat ini ialah Peraturan Pemerintah Nomor 38 Tahun 1997 tentang Peraturan Jabatan Pembuat Akta Tanah (LNRI Tahun 1997 Nomor 59, TLNRI Nomor 3696), selanjutnya disebut PPAT. Pasal 2 dan 3 Peraturan Jabatan PPAT pada intinya menyatakan, bahwa PPAT bertugas pokok melaksanakan sebagian kegiatan pendaftaran tanah dengan membuat akta otentik sebagai bukti telah dilakukannya perbuatan hukum tertentu mengenai hak atas tanah atau Hak Milik Atas Satuan Rumah Susun, yang akan dijadikan dasar bagi pendaftaran perubahan data pendaftaran tanah yang diakibatkan oleh perbuatan hukum itu. 
Perbuatan hukum yang dimaksudkan adalah: a) jual beli; b) tukar menukar; c) hibah; d) pemasukan ke dalam perusahaan (inbreng); e) pembagian hak bersama; f) pemberian Hak Guna Bangunan/Hak Pakai atas Tanah Hak Milik; g) pemberian Hak Tanggungan; h) pemberian kuasa membebankan Hak Tanggungan.

Mencermati dua ayat dalam Pasal 37 Peraturan Pemerintah Nomor 24 Tahun 1997 tentang Pendaftaran tanah, dianalisis sebagai berikut:

Pertama, Pasal 37 ayat (1) sesungguhnya tidak menentukan sah dan saat terjadinya jual-beli hak atas tanah, syarat-syarat jual beli hak atas tanah, dan saat peralihan hak atas tanah. Pasal ini hanya mengatur tentang pelaksanaan pendaftaran hak atas tanah. Namun demikian, karena Pendaftaran hak atas menentukan saat terjadinya peralihan hak atas tanah, maka peralihan hak atas hanya dapat dilakukan di hadapan PPAT. Peralihan hak atas tanah Menurut hukum adat yang berprinsip bahwa saat peralihan hak atas tanah terjadi seketika secara tunai, riil, dan terang, yaitu seketika diserahkan kepemilikan hak atas tanahnya dan dibayarnya harga, sedangkan prinsip hukum 'terang' mengandung makna wajib dilakukan di hadapan PPAT.

Kedua, Pasal 37 ayat (2) memungkinkan untuk mendaftar hak atas tanah yang peralihannya berdasarkan akta yang tidak dibuat oleh PPAT. Peralihan hak atas tanah yang dilakukan secara di bawah tangan atau dalam bentuk lain pun menurut ketentuan Pasal ini merupakan hal yang khusus karena keadaan tidak terdapatnya PPAT di daerah tertentu yang merupakan daerah terpencil. Hal ini tidak boleh ditafsirkan secara luas (penafsiran ekstensif), sehingga seakan-akan peralihan hak atas tanah dapat atau boleh dilakukan dengan akta yang tidak dibuat oleh PPAT.

Ketiga, mengenai tujuan diakuinya sebagai sesuatu yang sah jual beli yang tidak dilakukan dihadapan PPAT atau tidak dengan suatu akta otentik yang dibuat oleh PPAT, penjelasan Pasal 37 ayat (2) dengan jelas telah menentukan, yaitu untuk memudahkan rakyat melaksanakan perbuatan hukum mengenai tanah. Namun demikian, ketentuan Pasal 37 ayat (2) tidak dapat dibaca terpisah dengan ayat (1) nya. Mengenai frasa yang menyatakan 'Dalam hal tertentu sebagaimana yang ditentukan oleh Menteri', hal ini harus diberi makna bahwa Menteri akan menentukan Kantor Pertanahan mana saja yang dapat melakukan pendaftaran tanah terhadap peralihan hak atas tanah yang tidak dibuktikan dengan akta PPAT.

Dengan demikian, berdasarkan Peraturan Pemerintah Nomor 24 Tahun 1997 tentang 
Pendaftaran Tanah dan Peraturan Pemerintah Nomor 38 Tahun 1997 tentang Peraturan Pejabat Pembuat Akta Tanah, bahwa peralihan hak atas dapat didaftar berdasarkan akta yang dibuat dihadapan PPAT sebagai akta otentik maupun di daerah tertentu yang ditetapkan oleh Menteri berdasarkan akta di bawah atau bukti lain yang bukan akta PPAT.

Kedudukan PPJB-HAThak atas tanah yang dibuat oleh notaris berdasarkan kewenangan yang dimiliki sebagaimana ketentuan pasal 15 ayat (2) huruf f Undang Undang Jabatan Notaris harus diakui sebagai perjanjian yang sah, karena kewenangan tersebut secara normatif telah diatur dalam hukum positif. Para pihak dalam PPJB-HAT harus dipandang sebagai para subyek yang akan melakukan jual-beli hak atas tanah, dan belum melakukan jual-beli hak atas tanah. Dengan kata lain, jual beli hak atas tanah belum terjadi. Namun demikian, bagaimana jika dalam PPJB-HAT tersebut dinyatakan bahwa bahwa harga telah dibayar lunas oleh calon pembeli dalam kaitannya dengan hukum adat yang bersifat tunai dengan bersandarkan pada ketentuan Pasal 5 UUPA ?

Analisis mengenai kedudukan PPJB-HAT dalam perspektif hukum pertanahan dengan pendekatan Teori Positivisme, memberikan jawaban bahwa PPJB-HAT sesuai dengan Teori Positivisme, telah memiliki legitimasi berdasarkan Pasal 15 ayat (2) huruf f Undang Undang Jabatan Notaris. Akta yang berkaitan dengan Pertanahan sebagaimana dimaksud dalam Pasal 15 ayat (2) huruf f UUJN memiliki makna bersifat umum yang dapat berfungsi untuk mengisi kekosongan norma hukum yang bersifat khusus. Bahkan lebih jauh, Hukum Adat sebagai sumber hukum yang diakui oleh Pasal 5 UUPA sebagai dasar hukum bagi pengaturan Agraria pada umumnya dan Pertanahan pada khususnya, secara teoritis dapat menerima keberadaan PPJB-HAT yang mengidentikan dengan uang panjar dalam hukum adat.

Demikian pula jika PPJB-HAT ini didekati dengan Teori Positivisme Sosiologis sebagaimana dikemukakan oleh Theo Huijbers, bahwa dalam positivisme sosiologis hukum diterima dan diteliti semata-mata sebagai suatu gejala sosial, maka seandainya PPJB-HAT tidak dilandasi oleh ketentua Pasal 15 ayat (2) huruf $f$ pun, sesungguhnya secara sosiologis harus diterima sebagai hukum yang hidup dalam masyarakat sebagai suatu gejala sosial.

Kedudukan PPJB-HAT jika didekati dengan Teori Utilitarianisme atau Utilisme diperolah jawaban bahwa PPJB-HAT merupakan hukum yang hidup dalam masyarakat sebagai suatu gejala sosial dan lebih dapat memberikan kemanfaatan dari pada kemudharatannya. Kemanfaatan diartikan sebagai kebahagiaan (happiness) yang dalam praktik PPJB-HAT banyak dipilih oleh para pihak untuk melakukan pra-transaksi hak atas tanah. Artinya, PPJB-HAT menjadi hukum yang baik karena mampu memberikan kebahagiaan kepada para pihak yang akan melakukan transaksi hak atas tanah. 
Demikian pula keberadaan Pasal 5 UUPA haruslah dikaitkan dengan Ketentuan Pasal 18B ayat (2) UUD Negara Republik Indonesia Tahun 1945 (Perubahan Kedua) yang menyatakan bahwa: "Negara mengakui dan menghormati kesatuan-kesatuan masyarakat hukum adat beserta hak-hak tradisionalnya sepanjang masih hidup dan sesuai dengan perkembangan masyarakat dan prinsip Negara Kesatuan Republik Indonesia, yang diatur dalam undang-undang." Pengertian hak-hak tradisional dalam Pasal ini adalah pengertian tentang hukum tradisional, yaitu hukum Adat. Pengakuan atas eksistensi hukum Adat dalam Tata Hukum Nasional memerlukan proses untuk menjadi positif, dalam hal ini Pasal 5 UUPA, haruslah melalui pengaturannya dalam undang-undang. Hal demikian semula merupakan konsep Pasal 15 Algemene Berpalingen van Wetgeving pada zaman Hindia Belanda. Berdasarkan alur pikir demikian itu, maka hukum pertanahan yang dibangun berdasarkan hukum Adat harus dalam bentuk hukum positif berupa peraturan perundang-undangan.

\section{Akibat hukum pembayaran lunas harga dalam perjanjian pengikatan jual beli hak atas tanah}

Istilah yang dipakai dalam sub bab di atas adalah peralihan bukan beralih. Hal ini menunjukkan proses beralihnya hak atas tanah karena adanya pembayaran lunas terhadap harga dalam perjanjian pengikatan jual beli hak atas tanah. Analisis terhadap masalah ini untuk memperoleh jawaban, apakah dengan adanya pembayaran lunas terhadap harga hak atas tanah mengakibatkan hak atas tanah telah beralih atau justru sebaliknya belum beralih.

Pasal 5 Undang-undang Nomor 5 Tahun 1960 tentang Peraturan Dasar Pokok-Pokok Agraria (LN 1960-104, TLN No. 2043), selanjutnya disebut dengan Undang-Undang Pokok Agraria disingkat UUPA, menyatakan bahwa, "Hukum agraria yang berlaku atas bumi, air dan ruang angkasa ialah hukum adat, sepanjang tidak bertentangan dengan kepentingan nasional dan Negara,...segala sesuatu dengan mengindahkan unsur-unsur yang bersandar pada hukum agama".

Hukum perjanjian adat bersifat konkritatau kontan atau nyata atau riil. Hal ini sebagaimana dirumuskan oleh van Vollenhoven: "dat (in adatrecht) alle rechtsverhoudingen als rieel worden gedacht of reeel gemaakt" (bahwa dalam hukum adat) semua hubunganhubungan hukum dianggap sebagai konkrit/ nyata atau dibuat secara konkrit/nyata)". ${ }^{17}$

Pada jual-beli tanah menurut van Vollenhoven:

"de enkele (tot uiting gebrachte)
wilsovereenstemming door
partijen gedaan, nog geenszins een
overeenkomst tot stand brengt, want
om de adatrechtelijke binding te
krijgen moet er nog iet, zichbaars
(uiterlijk teken), aan te pas komen,
de z.g. "pandjer" (bindsom) in de
vorm van een geldstuk of een ander


zichbaar teken, die van koper op de verkoper overgaat". (pertemuan kehendak saja yang oleh para pihak telah dinyatakan, belum sekali-kali telah melahirkan suatu persetujuan, untuk mendapat suatu kekuatan mengikat menurut hukum adat, haruslah masih menjadi sesuatu yang nyata/konkrit/terlihat, yaitu penyerahan dari apa yang disebut "panjer" (alat pengikat) dalam bentuk sedikit uang atau benda lain yang nyata/terlihat yang diserahkan kepada si (calon) penjual oleh si (calon) pembeli. ${ }^{18}$

Penulis dihadapkan pada suatu pilihan pendapat para ahli yang saling berseberangan, setidaknya dalam dua hal, yaitu: pertama, apakah hukum pertanahan bersifat konsensuil ataukan bersifat riil/kontan, dan kedua, apakah PPJB-HAT dengan pembayaran lunas atas harga yang diperjanjikan mengakibatkan peralihan hak atas tanah ataukah tidak.

Terhadap hal yang pertama, maka penulis berpendapat, bahwa hukum pertanahan khususnya mengenai ketentuan Pasal 5 UUPA yang pada intinya menyatakan bahwa hukum yang berlaku atas bumi, air, dan ruang angkasa adalah hukum adat, selanjutnya harus dimaknai sebagai hukum yang hidup di dalam masyarakat. Masyarakat yang bersifat dinamis bukan statis. Hukum Adat tidak dapat dimaknai sebagai hukum yang diam dan tidak berkembang. Jika masyarakat adat dimaknai sebagai penduduk asli Indonesia atau orang Indonesia asli, maka praktik-praktik hukum yang berkembang dalam masyarakat sudah semestinya dimaknai sebagai perkembangan dari hukum adat itu sendiri. PPJB merupakan salah satu bentuk perkembangan hukum adat, hukum yang hidup dalam praktik transaksi hak atas tanah dalam masyarakat Indonesia.

Pertanyaaan yang mengemuka, apakah dengan demikian tidak bertentangan deng filosofi hukum agraria/pertanahan Indonesia, khususnya ketentuan Pasal 5 UUPA. Jawaban dari permasalahan ini ialah soal penafsiran norma hukum. Dalam tulisan ini, ketentuan Pasal 5 UUPA ditafsirkan sebagaimana penjelasan di atas.

Terhadap pembayaran sebagian ataupun pembayaran lunas ${ }^{19}$ terhadap harga hak atas tanah yang telah diperjanjian dalam PPJB, dianalisis, sebagai berikut: ${ }^{20}$

18 Ibid., hlm. 14.

19

20 Periksa juga pendapat Wirjono Prodjodikoro, Azas-Azas Hukum Perjanjian, (Bandung: Mandar Maju, 2011), hlm. 165, sebagai berikut:

"Menurut hemat saya, adalah lebih mudah dapat dimengerti oleh khalayak ramai yang bukan ahli hukum, apabila Sitem Hukum Adat dipilih untuk diberlakukan bagi segenap penduduk dan lagi sebetulnya Hukum BW pada pokoknya, lain daripada Hukum Perancis sudah agak mendekati Hukum Adat dengan menentukan, bahwa hak milik atas barang yang dijual baru beralih dari penjual kepada pembeli sesudah diserahkan kepada pembeli. Menurut Hukum Adat penyerahan hak milik yang dinamakan jual-beli yang sekali mengakibatkan beralihnya hak milik dari penjual kepada pembeli.Hanya saja harus diingat, bahwa hakekat dari Hukum Adat, yang sama sekali tidak memberi kekuatan kepada suatu perijinan belaka dari para pihak, adalah sukar untuk dipertahankan dalam keadaan lalu lintas modern dan internasional, yan sekarang makin lama makin maju dalam mempengaruhi hukum (rechtsleven) dari orang-orang Indonesia asli. Maka disamping menetapkan segala persetujuan tertentu adalah bersifat "reel", harus dibuka kemungkinan adanya pengikatan bagi kedua belah pihak dalam hal hanya ada perijinan saja dari mereka. Artinya: sebaiknya ditetapkan, bahwa dalam hal ini, apabila salah satu pihak tidak memenuhi janji, maka ia dapat dituntut mengganti kerugian, tidak seperti dalam BW untuk toh memenuhi janji”. 
Pertama, ditafsirkan sebagai panjar yang eksistensi pengaturan panjar tersebut dikenal baik dalam hukum adat maupun KUH Perdata. Walaupun substansi panjar itu sendiri berbeda antara hukum adat dan KUH Perdata yang disebabkan perbedaan azas dalam keduanya, hukum adat bersifiat riil/kontan sedangkan KUH Perdata bersifat konsensuil. Berdasarkan penafsiran ini, maka PPJB-HAT belum mengakibatkan haknya beralih kepada calon pembeli. Kedua, PPJB-HAT merupakan perjanjian formil, yaitu dengan syarat jual-beli hak atas tanah wajib dilakukan dihadapan PPAT, sehingga secara formil PPJB-HAT dengan pembayaran lunas belum mengakibatkan peralihan hak atas tanah dari penjual kepada pembeli. Dalam hal ini Akta PPAT dipandang sebagai bentuk pemenuhan syarat formil.

Pada perjanjian yang tergolong sebagai perjanjian formil (formal), tidak dipenuhinya ketentuan hukum tentang misalnya bentuk atau format perjanjian, cara pembuatan perjanjian, atau cara pengesahan perjanjian, sebagaimana diwajibkan melalui peraturan perundang-undangan, berakibat perjanjian formil batal demi hukum.

Pengertian perjanjian formil sebagai perjanjian yang tidak hanya didasarkan adanya kesepakatan para pihak, tetapi oleh peraturan perundang-undangan juga disyaratkan adanya formalitas tertentu yang harus dipenuhi agar perjanjian tersebut sah demi hukum.

Formalitas tertentu itu, misalnya tentang bentuk atau format perjanjian yang harus dibuat dalam bentuk tertentu, yakni dengan akta otentik atau surat dibawah tangan. Akta otentik yang dimaksud adalah akta yang dibuat oleh Notaris atau pejabat umum lain yang memiliki kewenangan untuk membuat akta otentik menurut peraturan perundangundangan.

Pengaturan oleh peraturan perundangundangan mengenai formalitas tertentu untuk perjanjian formil tersebut merupakan pengecualian dari asas konsensualitas dalam hukum perjanjian yang berlaku secara umum. Sebab, menurut asas konsensualitas, suatu perjanjian sudah terjadi dengan adanya kesepakan dari para pihak yang membuatnya. Kemudian agar perjanjian itu sah maka harus memenuhi syarat-syarat dalam Pasal 1320 KUH Perdata. Namun, asas tersebut tidak cukup untuk perjanjian formil karena masih ada formalitas lain yang diatur dalam peraturan perundang-undangan yang harus dipatuhi dan dipenuhi. Dengan demikian, perjanjian formil tidak cukup bila hanya berdasarkan asas konsensualitas.

Mengenai saat terjadinya Peralihan Hak Atas Tanah, bahwa terdapat perbedaan pendapat dari dua ahli hukum pertanahan masing-masing Saleh Adiwinata dan Boedi Harsono mengenai saat terjadinya peralihan hak atas tanah. Saleh Adiwinata berpendapat bahwa saat terjadinya peralihan hak atas tanah pada saat dilakukan pendaftaran tanah, sedangkan Boedi Harsono berpendapat pada saat ditandatanganinya Akta Pejabat Pembuat Akta Tanah (PPAT). Tentu akan terdapat 
pertanyaan berikutnya, apakah saat peralihan hak atas tanah tidak terjadi seketika harga dibayar lunas oleh Pembeli dalam Perjanjian Pengikatan Jual Beli Hak Atas Tanah.

Terhadap dua pendapat tersebut dianalisis, bahwa saat terjadinya peralihan hak atas tanah karena jual beli diketahui dengan pendekatan konsep hukum perdata, konsep hukum adat, maupun peraturan perundang-undangan pertanahan, sebagai berikut:

Kitab Undang-Undang Hukum Perdata mengatur tentang peralihan benda tidak bergerak, termasuk tanah dengan suatu penyerahan atau levering yang berbeda terhadap benda bergerak. Terhadap benda tidak bergerak, tanah misalnya, maka penyerahannya dengan suatu akta otentik.

Menurut Kartini Mulyadi dan Gunawan Widjaya, ${ }^{21}$ bahwa Penyerahan benda tidak bergerak menurut Pasal 616 Kitab Undang Undang Hukum Perdata harus dicatat dan didaftar dan selanjutnya dipublikasikan untuk umum, agar syarat untuk perolehan hak milik atas kebendaan tidak bergerak tersebut terpenuhi. Sebelum pendaftaran dan publikasi dilakukan (yang merupakan bukti levering atau penyerahan yang disyaratkan dalam Pasal 584 KUH Perdata), maka orang yang berdasarkan peristiwa perdata yang telah ditentukan (misalnya pembeli dalam suatu jual beli belum merupakan pemilik dari benda tidak bergerak tersebut. Selain itu pendaftaran juga merupakan bukti bahwa orang yang namanya terdaftar itulah yang merupakan pemilik dari benda tidak bergerak tersebut.

Bahwa terhadap benda tidak bergerak, Hak Milik sebagai hak kebendaan yang paling dasar (dan karenanya juga hak-hak kebendaan yang melekat dan mengikuti Hak Milik) baru lahir pada saat hak tersebut didaftar dan diumumkan menurut ketentuan Pasal 620 KUH Perdata. Maksud dari pendaftaran dan pengumuman tersebut adalah untuk melahirkan hak milik, sekaligus sebagai pengakuan akan keberadaan hak milik sebagai hak kebendaan (dan hak-hak kebendaan lainnya yang bersumber pada hak milik) oleh seluruh angota masyarakat dan karenanya memberikan hak yang bersifat mutlak atau absolut yang dapat dipertahankan oleh pemegang hak tersebut terhadap siapapun juga yang mengganggu haknya tersebut.

Perlu diketahui bahwa, meskipun dalam ketentuan Kitab Undang-Undang Hukum Perdata, pencatatan dan publikasi senantiasa dikaitkan dengan ketentuan Pasal 620 KUH Perdata, namun pasal tersebut tidak pernah berlaku sama sekali hingga dicabutnya ketentuan tersebut dengan Undang-undang Nomor 5 Tahun 1960 tentang Peraturan dasar Pokok Pokok Agraria. Adapun ketentuan yang mengatur mengenai pencatatan dan publikasi yang berlaku adalah yang dilakukan atau diselenggarakan berdasarkan pada pada ketentuan yang diatur dalam Overschrijvings Ordannantie 1834. 
Dalam ketentuan Overschrijvings Ordonnantie 1834 yang merupakan satau-satunya ketentuan yang berlaku sehubungan dengan pendaftaran benda tidak bergerak yang diatur dalam KUH Perdata, diberlakukan sistem registration of deed. Dalam sistem ini akta pemindahan hak dan akta pembebanan hak termasuk hipotek atas benda tidak bergerak tidak dibuat oleh notaris, melainkan oleh pejabat yang disebut dengan Overscrijvings Abmtenaar. Selanjutnya pendaftaran atas pemindahan hak dan pembebanan hak, termasuk hipotek atas benda tidak bergerak tersebut juga dilakukan oleh Overscrijvings Abmtenaar tersebut. Selanjutnya Overscrijvings Abmtenaar tersebut membubuhi nomor pendaftaran sesuai dengan urutan pendaftaran dalam register akta yang diselenggarakan olehnya sendiri.

Kegiatan pembuatan akta oleh Overscrijvings Abmtenaar dilaksanakan pada hari yang sama dengan kegiatan pendaftaran aktanya. Kepada pihak Pembeli, pihak yang memperoleh hak lebih lanjut, atau pemegang hipotik diberi Grosse Akta yang berfungsi sebagai bukti peralihan hak atau pembebanan hak.

Menurut konsep Hukum Adat, bahwa sifat perjanjian jual-beli hak atas tanah bersifat tunai, riil dan terang. Pembayaran lunas atas harga yang diperjanjikan dalam Perjanjian Pengikatan Jual Beli Hak Atas Tanah tidak merupakan atau menentukan saat beralihnya hak atas tanah dari penjual kepada pembeli dengan dua argumentasi: pertama, bahwa untuk melakukan perbuatan hukum berikutnya, pembeli masih memerlukan Kuasa dari penjual, dan kedua, bahwa Perjanjian Pengikatan Jual Beli masih wajib ditindaklanjuti dengan pembuatan Akta PPAT.

Berdasarkan dua argumentasi tersebut di atas, menunjukkan konsep hukum adat yang menentukan bahwa peralihan hak atas tanah bersifat riil menjadi tidak relevan, karena masih diharuskan adanya Kuasa dan Akta PPAT.

Pertanyaan yang mengemuka kemudian, jika memang saat peralihan hak belum atau tidak terjadi pada saat seketika harga dibayar lunas, karena masih harus ditindaklanjuti dengan pembuatan Akta PPAT sebagai syarat formil, apakah saat peralihan hak atas tanah terjadi seketika ditandatanganinya Akta PPAT oleh Penjual, Pembeli, Para Saksi, dan Pejabat Pembuat Akta Tanah. Dalam hal ini Penulis sependapat jika peralihan hak atas tanah karena jual-beli terjadi seketika dilakukan pendaftaran balik nama oleh Kantor Pertanahan.

Berdasarkan analisis demikian, maka peralihan hak atas tanah terjadi seketika dilakukan pendaftaran balik nama pada Kantor Pertanahan. Pembayaran lunas terhadap harga yang diperjanjikan saja dalam Perjanjian Pengikatan Jual Beli Hak Atas Tanah belum mengakibatkan haknya beralih kepada pembeli. Demikian pula dengan dibuatnya Akta PPAT peralihan hak atas tanah belum terjadi, karena masih belum terdapat kepastian hukum pemegang hak atas tanah serta belum mengikat pihak ketiga. 
Mengenai pendaftaran peralihan hak atas tanah, terdapat konsep yang dianut oleh hukum adat dan secara implisit dianut oleh UUPA. Bentuk peralihan hak dilakukan secara tunai dan terang. Terang berarti harus dilakukan dihadapan pejabat yang berwenang yakni PPAT.

Menurut Pasal 2 ayat (1) Peraturan Jabatan PPAT, bahwa PPAT bertugas pokok melaksanakan sebagian kegiatan pendaftaran tanah dengan membuat akta sebagai alat bukti telah dilakukannya perbuatan hukum tertentu mengenai hak atas tanah atau Hak Milik Atas Satuan Rumah Susun, yang akan dijadikan dasar bagi pendaftaran perubahan data pendaftaran tanah yang dilakibatkan oleh perbuatan hukum itu.

Sedangkan perbuatan hukum yang dimaksud pada Pasal 2 ayat (2), antara lain ialah jual beli. Kewenangan PPAT dalam menjalankan tugas pokok sebagaimana dimaksud pada Pasal 2 Peraturan Jabatan PPAT ialah membuat akta otentik mengenai suatu perbuatan hukum terhadap hak atas tanah, antara lain perbuatan hukum jual beli hak atas tanah.

Persoalan kemudian, apakah dengan alat bukti berupa akta otentik yang dibuat oleh dan dihadapan PPAT tersebut mengakibatkan terjadinya peralihan hak, ataukah masih memerlukan persyaratan lain berupa pendaftaran peralihan hak atas tanah untuk terjadinya peralihan hak atas tanah berupa jual beli tersebut. Dengan kata lain, apakah pendaftaran peralihan hak merupakan syarat terjadinya peralihan hak atas tanah dalam perspektif hukum pertanahan.

Terhadap persoalan tersebut dianalisis, sebagai berikut: bahwa tujuan pendaftaran tanah, termasuk pendaftaran tanah dalam rangka pemeliharaan data pertanahan, ialah untuk memberikan kepastian hukum bagi pihak-pihak yang melakukan perbuatan hukum maupun terhadap pihak ketiga. Pasal 19 UUPA menyatakan, bahwa:

“(1) Untuk menjamin kepastian hukum oleh Pemerintah diadakan pendaftaran tanah di seluruh wilayah Republik Indonesia menurut ketentuan yang diatur dengan Peraturan Pemerintah".

(2) Pendaftaran tersebut dalam ayat

(1) pasal ini meliputi:

a. pengukuran, perpetakan dan pembukuan tanah;

b. pendaftaran hak-hak atas tanah dan peralihan hak-hak tersebut;

c. pemberian surat-surat tanda bukti hak, yang berlaku sebagai alat pembuktian yang kuat".

Berdasarkan ketentuan Pasal 19 ayat (1) dan ayat (2) UUPA tersebut, tampak bahwa pendaftaran peralihan hak diadakan untuk menjamin kepastian hukum, dalam hal ini, kepastian hukum telah terjadi peralihan hak atas tanah. Demikan pula jika dicermati ketentuan Pasal 23, 32, dan 38 UUPA, maka pendaftaran peralihan hak tersebut bersifat suatu keharusan dan dimaksudkan agar para pemegang hak atas tanah memperoleh kepastian tentang haknya itu.

Dengan analogi, bahwa pendaftaran peralihan hak atas tanah memberikan kepastian 
hukum, dan pendaftaran peralihan hak atas tanah memberikan kepastian pemegang hak atas tanah, sehingga pendaftaran peralihan hak atas tanah, memberikan kepastian hukum pemegang hak atas tanah.

Berdasarkan analisis pada sub bab ini, maka pendaftaran peralihan hak atas tanah merupakan kewajiban untuk memperoleh kepastian hukum saat terjadinya peralihan hak atas tanah, serta kepastian hukum pemegang hak atas tanah.

\section{Simpulan}

Berdasarkan analisis di atas dapat disimpulkan, bahwa:
Kedudukan PPJB-HAT dapat diterima sebagai hukum yang hidup dalam praktik masyarakat Indonesia, serta untuk mengisi kekosongan norma hukum dalam perspektif hukum pertanahan.

Pembayaran lunas terhadap harga dalam PPJB-HAT belum mengakibatkan beralihnya hak atas tanah dari penjual kepada pembeli, namun hanya merupakan panjar atau tanda jadi (voorschot). Peralihan hak atas tanah merupakan perjanjian formil (formal), sehingga peralihan hak kebendaan berupa hak atas tanah memerlukan syarat formil (formal). Peralihan hak atas tanah terjadi seketika pada saat dilakukan pendaftaran balik nama pada Kantor Pertanahan.

\section{DAFTAR PUSTAKA}

\section{Buku}

Adiwinata, Saleh. Pengertian Hukum Adat Menurut Undang Undang Pokok Agraria. Bandung: Alumni, 1976.

Hadikusuma, Hilman. Hukum Perjanjian Adat. Bandung: Alumni, 1982.

Hartono, Sunaryati. Politik Hukum Menuju

Suatu Sistem Hukum Nasional. Bandung: Alumni, 1991.

Mulyadi, Kartini \& Gunawan Widjaja.

Kebendaan Pada Umumnya. Jakarta: Kencana, 2005

Prodjodikoro, Wirjono. Azas-Azas Hukum

Perjanjian. Bandung: Mandar Maju, 2011.

Setiady, Tolib. Intisari Hukum Adat Indonesia-

Dalam Kajian Kepustakaan. Bandung:

Alfabeta, 2008.
Sofwan, Sri Soedewi Masjchoen. Hukum Perdata: Hukum Benda. Yogyakarta: Liberty, 1975.

Subekti, R. Aspek-Aspek Hukum Perikatan Nasional. Bandung: Citra Aditya Bakti, 1998.

\section{Naskah Internet}

Alfiansyah. "Urgensi Perjanjian Pengikatan Jual Beli (PPJB) Hak Atas Tanah Yang Dibuat Oleh Notaris“, http://hukum. studentjournal.ub.ac.id/index.php/ hukum/article/view/1322. Diakses 11 Januari 2017. 